The Japanese Journal of Animal Psychology, 43-1-2, 17-23 (1993)

資 料

メスマウスにおける求交尾的接近の系統差 ${ }^{1)}$

筑波大学 富 原一哉

\title{
Strain Difference in Proceptive Approach in Female Mice
}

\author{
KAZUYA TOMIHARA \\ Institute of Psychology, University of Tsukuba
}

Beach (1976) は，彗歯類のメスの役割を三つ の側面に分けてとらえることを提唱した。第一 は，誘引性 (attractivity)である。誘引性とは, オスの性的相互作用を喚起させる機能であり, メスの匂いや形態などの刺激側面をさす。第二 の求交尾性 (proceptivity) は, 一旦喚起された 性的相互作用を維持し, 交尾の完了に至らせよ うとする行動を指している。つまり，メスが交 尾を求めてオスに対して示す欲求行動 (appetitive behavior) である。ラットにおい てメスは発情期に hopping や darting などの 特徴的な行動を示し,オスを誘惑することから， これらの行動がラットにおけるメスの求交尾的 行動であると考えられている。第三の受容性 (receptivity) は，オスが腔内射精に達するの に必要かつ充分なメスの反応, 簡単に言うと, メスがロードシス (lordosis) 反応を示してオス

1) 本研究の実施にあたり、実験に協力下さった 筑波大学人間学類卒業生の辻本明君に感謝の意 を表します。
の交尾行動を受け入れることである。

ラットにおいてはメスに関する様々な研究が あるが，マウスに関してはそのようなメスの役 割に関しては従来ほとんど報告がなかった。そ の最大の理由はメスマウスが発情期でも基本的 に拒絶行為を示し，ラットのように簡単に求交 尾的行動として同定されるような特徵的な行動 型を持たないために，その研究が困難であった からだと思われる（富原・牧野，1990）。

富原・牧野（1991 a）は, 雌雄の性行動の詳細 な観察を行うことにより，メスから接近した方 が，オスがマウントしたときにロードシスへと 進展しやすく, 腔内への挿入も容易になるとい うことを明らかにした。つまり，メスマウスは ラットの hopping や darting のように特徵的 な求交尾的行動は持たないものの, 交尾過程に おいて自ら積極的にオスに接近することによ り, 交尾成立の促進を行っているのである。し たがって, 彼らは性的相互作用過程におけるこ のメスからの接近をマウスの求交尾的行動（求 交尾的接近）と位置づけることができると考え 
たのである。また，このような求交尾的接近の 発現には，交尾経験が重要であることも示され ている（富原・牧野，1992）。

ところで，多くの近交系を有するマウスにお いては，性行動の諸側面でさまざまな系統差が 存在することが知られている (e.g. Levine, Barsel \& Diakow, 1966; McGill, 1962; McGill \& Blight, 1963; McGill \& Ransom, 1968 ; Mosig \& Dewsbury, 1976 ; 富原・牧野, 1991b；Vale \& Ray, 1972)。例えば，DBA 系 マウスは少ない回数の挿入とスラストで射精に 達する点で非常に効率よく交尾を行い (McGill, 1962)，逆に CBA 系マウスは様々な側面におい て交尾の効率が低いという特徴を持っている (Levine, et al., 1966)。このような系統差の多 くは，これらの近交系マウスの遺伝的差異に基 づくものと考えられている。

先に述べたメスマウスの求交尾性に関して は，近交系を用いてその遺伝的差異を検討した 研究は未だ見あたらない。富原・牧野 (1991 a, 1992）の研究ではクローズドコロニーである ICR 系のマウスが用いられているが，やはりこ れまで報告されてきたのと同じように求交尾的 行動に関しても系統差が認められる可能性があ る。本研究では, 交尾の効率の大きな差のある DBA と CBA の 2 系統の近交系マウスの性行 動を観察し，メスの求交尾的接近を中心に比較 することを目的として行われた。

\section{方 法}

被験体：2系統の近交系マウス $\mathrm{DBA} / 2 \mathrm{~J}$, $\mathrm{CBA} / \mathrm{Ca}$ の雌雄それぞれ 20 匹, 計 80 匹を被験 体として用いた。富原・牧野（1991 a）に従い, メスは交尾，妊娠，出産，育児を含めた性的経 験のあるもの，オスは性的にナイーヴなものを 用いた。これは，そのような組み合わせの方が 性的相互作用におけるメスの役割の重要性がよ り発揮されると考えられる(富原・牧野, 1991 a) からであり，また，メスの求交尾的接近の発現 には，オスとの性的経験が必要であることが明
らかとされているためである（富原・牧野, 1992)。被験体は, 12 時間 on / 12 時間 off の照 明サイクル下で維持され, 餌・水は自由に摂取 できるようにした。

装置：265×425×200 mm の透明なプラスチッ クケージを，行動観察テスト用に用いた。また 行動の記録のため, ビデオ録画装置を用いた。

手続き：行動テストは，暗期に赤色照明下で行 われた。テストの直前に，メスの胵スミア

(Vaginal smear) を観察し，発情期にあるメス を被験体として用いた。まず観察用ケージにオ スの被験体を投入し，1時間放置した。その後 メスを投入し，観察を開始した。なお，被験体 の行動はビデオで録画した。テスト時間は，才 スが射精に達するまでか，あるいはテスト開始 より 6 時間とした。

分析：行動テスト終了後ビデオ録画を再生し, オスの被験体に関しては, Dewsbury et al. (1979)の用いたオスの性行動に関する13の量 的パラメータに, Number of attempted mounts（NAM）を加えた 14 項目について測 定を行った（Table 1)。これらは蛪歯類の性行 動研究で一般的に用いられているパラメータで ある。

また，これまでの研究により，マウント直前 にメスから接近した場合には，オスから接近し た場合よりもメスはロードシスを示しやすく， 結果として実際に挿入を伴ったマウントの頻度 が高くなることが明らかになっている。そこで， 本研究ではその点にのみ注目して，メスの行動 の分析に関しては，オスから接近してマウント を仕掛けた場合とメスから接近したときにオス がマウントを仕掛けた場合とで，その後のマウ ントの成功率, メスのロードシス商, 挿入の頻 度などが異なるかどうかを比較検討することと した。

\section{結果と考察}

交尾の成立：実験に用いられた被験体のうち， 6 時間以内に射精まで終了したのは, DBA では 
Table 1 Behavioral descriptions of fourteen parameters of male copulatory behavior.

1. ML (Mount latency)：最初のマウントあるいは挿入を伴うマウントまでの秒数。

2. IL (Intromission latency) : 最初の実際の挿入が始まるまでの秒数。

3. EL (Ejaculation latency)：最初の挿入から射精反射が起こるまでの秒数。

4. III (Interintromission interval)：挿入を伴うマウントから次の扦入を伴うマウントまでの秒数。

5. TI (Time of intromission)：挿入を伴うマウントの開始から、マウントの終了あるいは射精反射の 開始までの時間。

6. TM (Time of mount)：挿入を伴わないマウントの持続秒数。

7. ED (Ejaculation duration)：射精からマウントの終了までの間にオスがメスを垷んでじっとして いる秒数。

8. PIMD (Preintromission mount duration) : 挿入を伴うマウントが開始してから, 最初の胵内で のスラストが起こるまでの秒数。

9. TNT (Total number of thrusts)：射精反射までの胵内でのスラスト総数。

10. NI (Number of intromission in a series) : 射精反射を導いた挿入を含めての一シリーズ内での挿 入頻度。

11. Th/I (Thrusts per intromission)：射精時の挿入を含む挿入毎の平均スラスト数。

12. NM (Number of mounts)：シリーズ内での挿入を伴わないマウント数。

13. NHM (Number of head mounts) : シリーズ内での、メスの頭の側からのマウント数。

14. NAM (Number of affempted mounts) : シリーズ内での、不完全なマウント数。スライトはみら れるが，前肢をメスのわき腹に置くことはできない。

Table 2 Comparison of medians in fourteen parameters of copulatory behavior between two strains.

\begin{tabular}{lcc}
\hline Parameters & $\begin{array}{c}\text { DBA } \\
\mathrm{n}=11(\mathrm{n}=8)\end{array}$ & $\begin{array}{c}\text { CBA } \\
\mathrm{n}=9(\mathrm{n}=4)\end{array}$ \\
\hline ML & 5375 & 1554 \\
IL & 5697 & 5623 \\
EL & $(5267)$ & $(8441)$ \\
III & 89 & 175 \\
TI & 13 & 13 \\
TM & 4 & 5 \\
ED & $(19)^{*}$ & $(26)$ \\
PIMD & 2 & 2 \\
TNT & 402 & 467 \\
NI & 47 & 41 \\
Th $/ \mathrm{I}$ & 12 & 10 \\
NM & $11^{*}$ & 50 \\
NHM & 0 & 0 \\
NAM & $0^{*}$ & 7 \\
\hline
\end{tabular}

Values except in TNT, NI, Th/I, NM, NHM, and NAM were indicated in seconds. Values in paratheses were obtained from animals which reached ejaculation.
20 ペア中 8 ペア, CBA では 20 ペア中 4 ペアで あった。さらに, 射精にまでは至らなかったも のの,メスがロードシスを示し, 挿入をともなっ たマウントが成立したものは DBA では 3 ぺ ア, CBA では 5 ペアあった。残りのペアに関し ては，DBAに扔いても CBAにおいても，メス はほとんどロードシスを示さず，マウントの成 立回数も少なかったので分析から除外した。し たがって, DBA では 11 ペア, CBA では 9 ペア を以降の分析に用いることとした。

量的パラメータ: Table 2 は, さきに述べたオ スの性行動の量的パラメータについて, 系統毎 の平均值を示したものである。また, Fig.1 は量 的パラメータの結果をもとに両系統の交尾パ ターンを模式化した図である。これらを見ると， $\mathrm{DBA}$ は CBA よりも短時間で交尾を成功させ ていることが分かる。つまり, DBA は CBA よ りも遅くマウントを始めるが，そこから実際の 挿入までの時間は短く，早くマウントを始めた $\mathrm{CBA}$ と同じ頃に実際の扦入を行い, そこから， 短い間隔で挿入を繰り返して, CBA よりも早く 


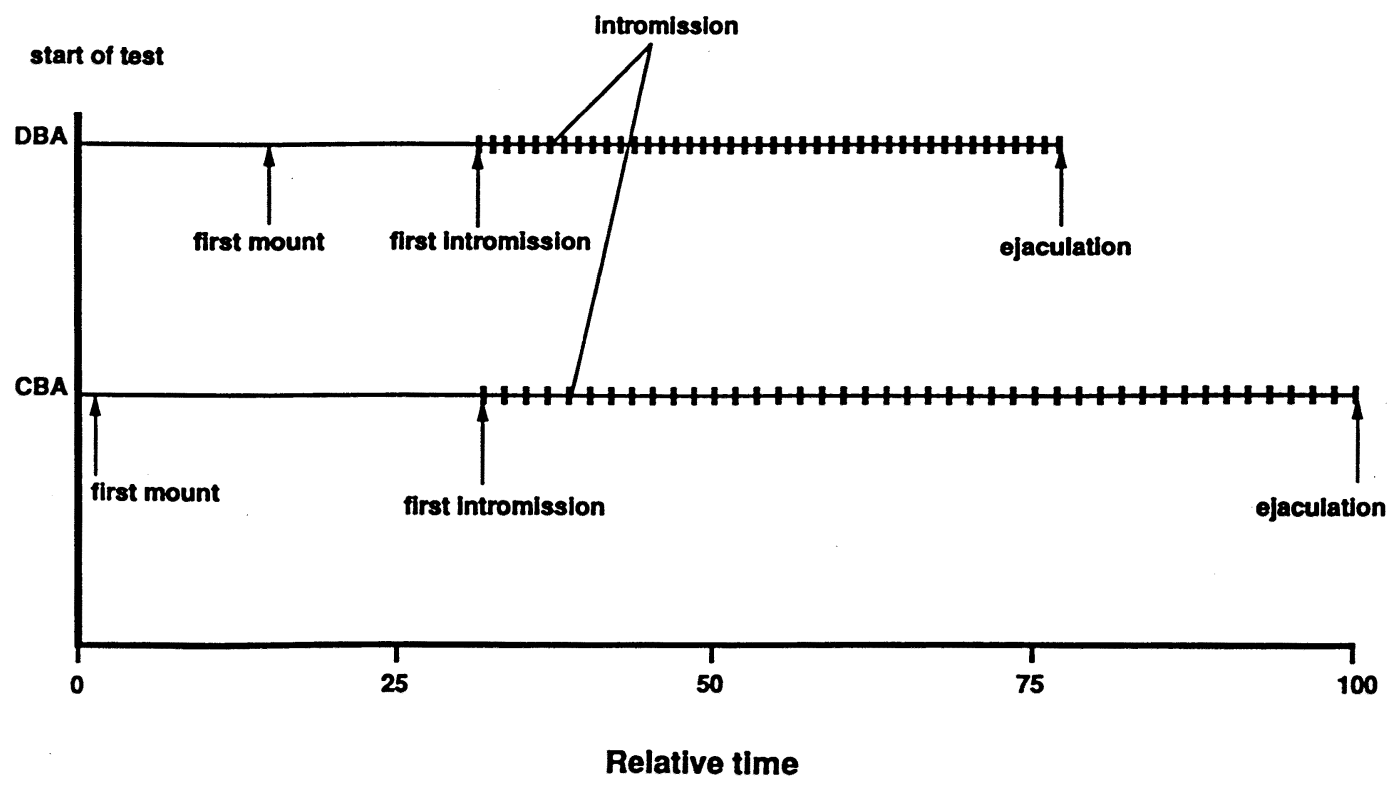

Fig. 1 Time course of copulatory behavior of $\mathrm{DBA} / 2 \mathrm{~J}$ and $\mathrm{CBA} / \mathrm{Ca}$ strains

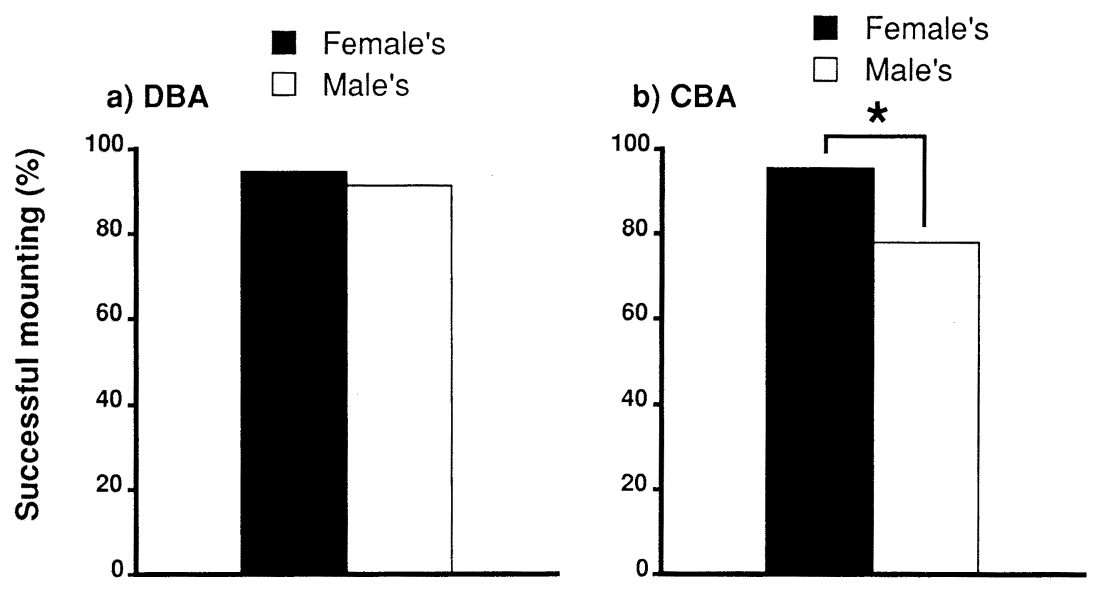

Fig. 2 Percentage of successful mounting preceded by female's and male's approach $\left({ }^{*} \mathrm{p}<.05\right)$

射精に至るのである。統計的にも, CBA では挿 入を伴わないマウント $(\mathrm{NM}: \mathrm{U}$ 検定 $: z=2.47$, $\mathrm{p}<.05)$ やマウントの失敗（NAM：U 検定： $\mathrm{z}=2.11, \mathrm{p}<.05)$ が多く, 射精後倒れている時間 $(\mathrm{ED}: \mathrm{U}$ 検定 $: z=1.96, \mathrm{p}<.05)$ が長いことが 示され, DBA のほうが短時間で交尾を成功さ
せたことを裏付けている。

メスの役割：DBA ではマウントの成功率 (Fig. 2 a)，メスのロードシス商（Fig. 3 a）ともに， オスから接近した場合もメスから接近した場合 もほぼ 100\%に近い非常に高い率で，接近者の 性による差が認められなかった。一方 CBA で 

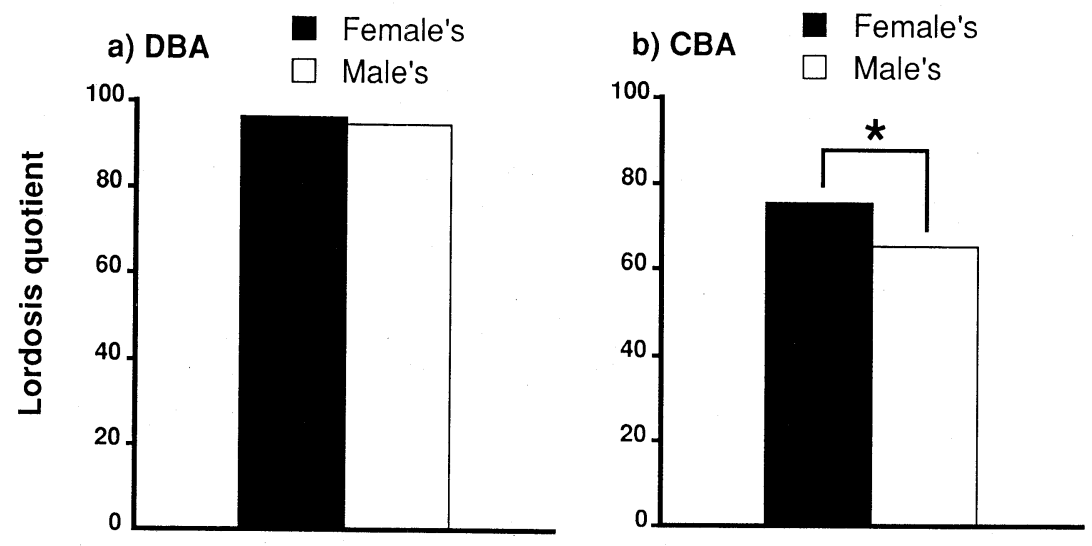

Fig. 3 Lordosis quotient preceded by female's and male's approach $(* \mathrm{p}<.05)$
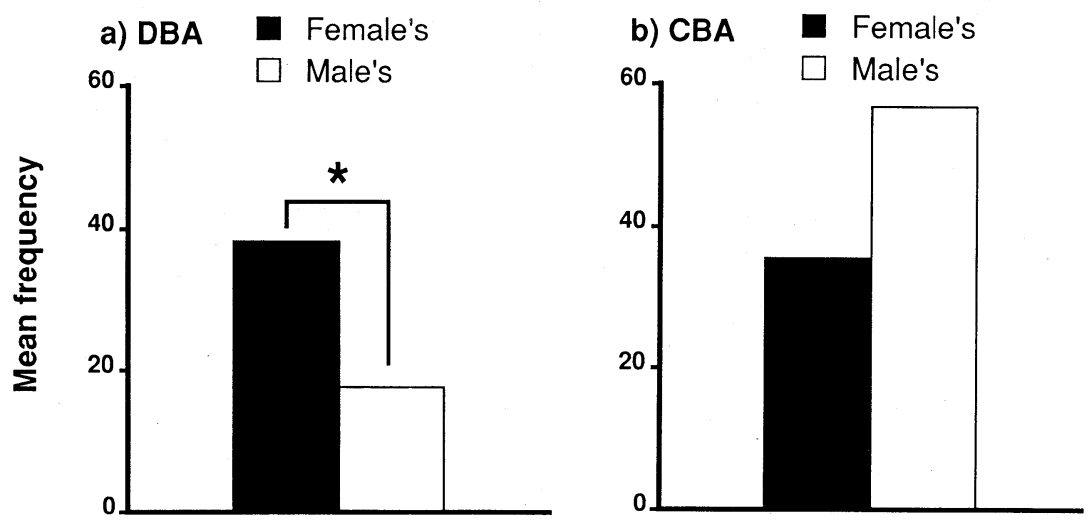

Fig. 4 Mean frequency of mounting preceded by female's and male's approach $\left({ }^{*} \mathrm{p}<.05\right)$

は，メスから接近したときの方がマウントが成 功しやすく（Fig. 2 b：Wilcoxon の符号化順位 検定 $: n=9, \mathrm{R}=0, \mathrm{p}<.05)$, メスのロードシス 商も高かった(Fig. $3 \mathrm{~b}$ : Wilcoxonの符号化順 位検定： $\mathrm{n}=9, \mathrm{R}=0, \mathrm{p}<.05)$ 。したがって, CBA では，メスからオスに対する接近は，富原・牧 野(1991 a) が報告したものと同じく，メスが交 尾の主導権を掌握しようとする求交尾的機能を 有していると考えられる。

一方，オスから接近した場合とメスから接近 した場合のマウントの生起頻度を比較すると, DBA ではメスから接近した場合に非常に多く
マウントが生起し（Fig. $4 \mathrm{a}$ ：Wilcoxon の符号 化順位検定 : $\mathrm{n}=11, \mathrm{R}=3.5, \mathrm{p}<.05)$, 実際の挿 入の回数もメスから接近した場合に多いことが 明らかとなった（Fig. 5 a：Wilcoxon の符号化 順位検定 $: \mathrm{n}=11, \mathrm{R}=1.5, \mathrm{p}<.05)$ 。

先に述べたように，DBA ではオスから接近 したときもメスから接近したときも常に $100 \%$ に近い率でマウントが成功し，メスはロードシ スを示している。したがって，この結果からだ けでは，DBA では富原・牧野（1991 a）が報告 したようにメスから接近したときの方が交尾が 進展しやすいとは結論できない。しかしながら， 


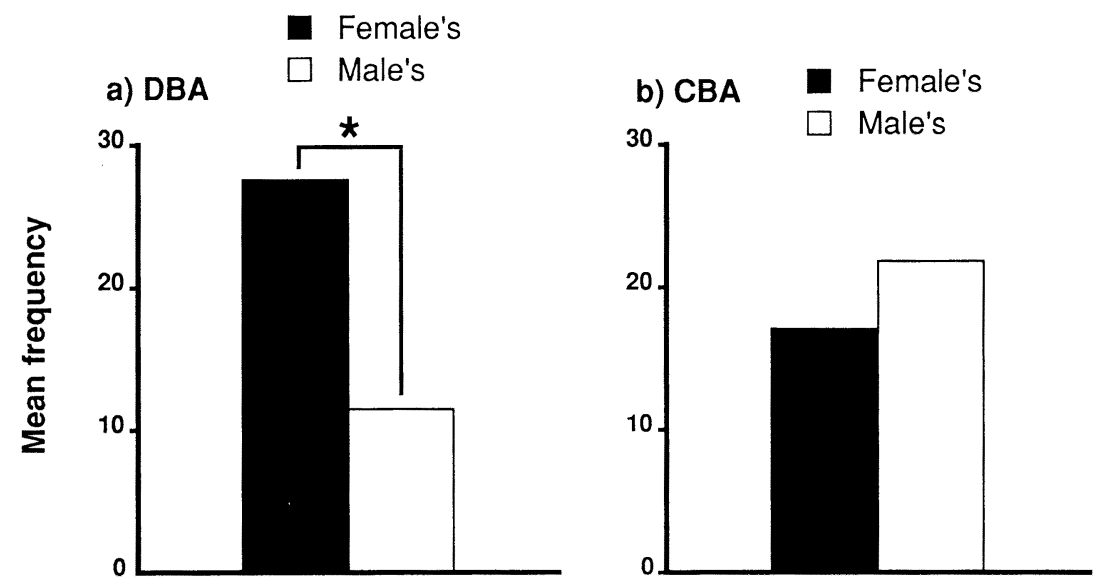

Fig. 5 Mean frequency of intromission preceded by female's and male's approach.

DBA では，オスから接近したときょりもメス から接近したときの方がマウントや挿入の頻度 が多くなっている。つまり，メスはマウントや 挿入につながる接近の頻度を多くすることで交 尾の主導権を掌握していると考えられるのであ る。したがって，その発現パターンは富原・牧 野（1991 a）が用いたICRや本研究における CBA とは異なるものの, DBA においてもメス からの接近は求交尾的機能を有していると結論 できるように思われる。

逆にCBA の場合は, 先に述べたように, マウ ントの成功率もメスのロードシス商もメスから 接近したときの方がオスから接近したときょり も高かったが, マウントの生起頻度 (Fig.4 b) や挿入頻度（Fig.5 b）は，オスから接近した場 合の方が高かった（ただし，どちらも統計的に は有意ではない)。これは, CBA のオスが自ら 積極的に接近し，マウントを仕掛けることで, 自ら接近した場合の成功率の低さを補っている と見ることができる。CBAの場合は, メスから の接近に求交尾的機能は認められるものの, そ のことによってメスが交尾の主導権を握ってい るとはいい難く,むしろオスが積極的に接近し， 自らに主導権を呼び戻していると考えることが できよう。
以上, DBA と CBA の両系統の間には求交尾 的接近の発現パターンに系統差が認められ, DBA ではメスから接近したときにマウント頻 度や挿入頻度が多く, CBA ではメスから接近し たときにロードシス商やマウント成功率が高い という形でその効果が現れることが明らかと なった。これらのメスの求交尾的接近における 系統差は, 両系統の遺伝的差異に基礎を置くも のと考えられる。

\section{要 約}

Beach (1976) はメスがオスに交尾を求めて示 す欲求行動を求交尾的行動 (proceptive behavior）と呼んだ。マウスにおけるメスの求交尾的 行動はほとんど報告されてこなかったが, 雌雄 の性行動の詳細な観察を行った研究において, メスからオスに接近することが性的相互作用に おいてその後の交尾を前進的に進展させる求交 尾行動（求交尾的接近）であることが示唆され た(富原・牧野, $1991 \mathrm{a})$ 。本研究では, DBA/2 J と $\mathrm{CBA} / \mathrm{Ca}$ の 2 系統の近交系マウスの性行動 を観察することにより，このようなメスの求交 尾的接近に系統差が存在するのかどうかを明ら かにしようとした。

被験体としてDBA とCBA の雌雄それぞれ 
20 ペアを用い, 性的経験を有するメスと性的に ナイーヴなオスをぺアとして性行動の観察を 行った。観察はオスが射精に達するか, 実験開 始から 6 時間経過するまで続けられた。

分析には 6 時間以内に挿入を伴ったマウント が認められた DBA 11 ペア, CBA 9 ペアを用い た。その結果 DBA は効率的に交尾を行い, 比較 的早く射精に至り,CBA はマウントの失敗が多 いなど効率が悪く，射精にまで時間がかかるこ とが明らかとなった。また，メスのオスに対す る接近には両系統とも求交尾的機能が認められ るものの，そのパターンには差異があり，DBA ではメスから接近したときにマウント頻度や挿 入頻度が多く,CBA ではメスから接近したとき にロードシス商やマウント成功率が高かった。

\section{REFERENCES}

Beach, F. A. 1976 Sexual attractivity,proceptivity, and receptivity in female mammals. Hormones and Behavior, 7, 105-138.

Dewsbury, D. A., Oglesby, J. M., Shea, S. L., \& Connor, J. L. 1979 Inbreeding and copulatry behavior in house mice: A further consideration. Behavior Genetics, 9, 151-163.

Levine, L., Barsel, G. E., \& Diakow. C. A. 1966 Mating behavior of two inbred strains of mice. Animal Behaviour, 14, 1-6.

McGill, T. E. 1962 Sexual behavior in three in- bred strains of mice. Behaviour, 19, 341-350.

McGill, T. E. \& Blight, W. C. 1963 The sxual behavior of hybrid male mice compared with the sexual behavior of males of the inbred parent strains. Animal Behaviour, 11, 480-483.

McGill, T. E. \& Ransom, T. W. 1968 Genotypic change affecting conclusions regarding the mode of inheritance of behavior. Animal Behaviour, 16, 88-91.

Mosig, D. W. \& Dewsbury, D. A. 1976 Studies of copulatory behavior of house mice (Mus musculus). Behavioral Biology, 16, 463-473.

富原一哉・牧野順四郎 1990 マウスにおける性行動 研究の最近の動向 筑波大学心理学研究, 12, 57-67.

富原一哉・牧野順四郎 1991a マウスの性的相互作用 におけるメスの積極的役割 心理学研究, 62, 294-300.

富原一哉・牧野順四郎 1991b 近交系マウスの出会わ せテスト場面における性行動の系列構造 筑 波大学心理学研究, 13, 105-111.

富原一哉・牧野順四郎 1992 メスマウスの求交尾的 接近に及ぼす性的経験と初期経験の影響 動 物心理学研究, 42, 1-8.

Vale, J. R., \& Ray, D. 1972 A diallel analysis of male mouse sex behavior. Behavior Genetics, 2, 199-209. 